Check for updates

Cite this: RSC Adv., 2017, 7, 38399

Received 31st May 2017

Accepted 17th July 2017

DOI: $10.1039 / c 7 r a 06079 c$

rsc.li/rsc-advances

\section{Synthesis and ecotoxicological impact of ferrocene-derived amino-phosphonates using a battery of bioassays $\uparrow$}

\author{
J. Lewkowski, iD *a R. Karpowicz, ${ }^{a}$ M. Morawska, ${ }^{a}$ P. Rychter, ${ }^{\star b}$ D. Rogacz, ${ }^{b}$ \\ K. Lewickab and P. Dobrzyński iD bc
}

Due to the fact that $\alpha$-aminophosphonates are structurally analogous to $\alpha$-amino acids, the search for new biologically active agents based on the chemistry of these compounds has stimulated growing interest. Although there is increasing attention focused on the various applications of these compounds, there is poor information about their ecotoxicological impact on the environment. In this study, ferrocenederived aminophosphonates have been synthesized and their environmental impact on selected plants, namely Avena sativa and Raphanus sativus as well as on the bacteria Vibrio fischeri, and the crustacean Heterocypris inconguens, has been assessed and their ecotoxicological profile determined.

\section{Introduction}

Aminophosphonic systems have found application in the area of environmental protection, and have been successfully applied as herbicides for over 20 years (e.g. glyphosate), being especially known as the inhibitors of various plant enzymes. ${ }^{1}$ New examples are still being investigated with respect to their potential application in agrochemistry and their synthesis and the assessment of their bioactivity in plants have been reported quite recently. ${ }^{2-4}$ Ferrocene derivatives have attracted attention since the discovery of their fascinating properties, ${ }^{5}$ providing prospects for their application as redox controlled molecular switches. Their biological properties are also very promising. Jaouen et al. ${ }^{6}$ published the first report of a tamoxifen-based ferrocene derivative, which was found to be an effective estrogen receptor blocker. Studies on the potential applications of ferrocene derivatives as anticancer hormonal agents were described later on. ${ }^{7,8}$ The antimalarial activity of ferrocene-derived artemisinin, artemisitene or quinine were also reported. ${ }^{9}$

For us, the most interesting reports were on some attempts to apply ferrocene derivatives in agriculture, ${ }^{\mathbf{1 0 , 1 1}}$ describing their herbicidal, ${ }^{\mathbf{1 0}}$ antifungal, ${ }^{\mathbf{1 1}}$ larvicidal $^{\mathbf{1 1}}$ or plant regulatory ${ }^{\mathbf{1 1}}$ properties. The idea of synthesizing aminophosphonic

${ }^{a}$ Department of Organic Chemistry, Faculty of Chemistry, University of Łódź, Tamka 12, 91-403 Eódź, Poland. E-mail: jlewkow@uni.lodz.pl

${ }^{b}$ Institute of Chemistry, Environmental Protection and Biotechnology, Jan Dlugosz University in Czestochowa, 13/15 Armii Krajowej Av., 42-200 Czestochowa, Poland. E-mail: p.rychter@ajd.czest.pl

${ }^{c}$ Centre of Polymer and Carbon Materials, Polish Academy of Sciences, M. CurieSkłodowskiej 34, 41-819 Zabrze, Poland

$\dagger$ Electronic supplementary information (ESI) available: NMR spectra of imines 1a-b, NMR spectra of aminophosphonates 2a-d and digital photographs of studied plants. See DOI: $10.1039 / \mathrm{c} 7 \mathrm{ra06079c}$ derivatives of ferrocene arose almost twenty years $\operatorname{ago}^{12 a}$ and since that time, we have synthesized a series of ferrocenederived aminophosphonates and aminophosphonates ${ }^{\mathbf{1 2}}$ and tried to investigate their molecular properties. ${ }^{12 e_{2} f}$

In view of the above, nobody can deny the potential usefulness of aminophosphonates as biological agents. According to REACH regulations (Registration, Evaluation, Authorization and Restriction of Chemicals), there is an urgent need to follow the environmental behaviour of new compounds to avoid unexpected, harmful effects on the environment. Proposed by European Chemicals Agency (ECHA), ecotoxicological testing is an essential tool for evaluating the effects of chemicals on the environment, and even more, it is required for REACH registration of new chemical compounds. It has to be taken into consideration that newly synthesized compounds, especially potentially bioactive $\alpha$ aminophosphonic derivatives, may cause environmental risk. Therefore, the objective of this study is to evaluate the phytotoxicity of four novel, ferrocene-derived aminophosphonates, namely: dimethyl $\mathrm{N}$-(4-methoxyphenyl)amino(ferrocenyl)methylphosphonate (2a), dimethyl $N$-(4-methylphenyl)amino(ferrocenyl)-methylphosphonate (2b), dibenzyl $N$-(4-methoxyphenyl)-amino(ferrocenyl)methylphosphonate (2c) and dibenzyl $N$-(4-methylphenyl)amino(ferrocenyl)methylphosphonate against dicotyledonous radish (Raphanus sativus) and monocotyledonous oat (Avena sativa). Ecotoxicological assessment was also performed using Vibrio fischeri bacteria and Heterocypris incongruens crustaceans.

\section{Experimental}

Chemistry - general

All solvents (POCh, Gliwice, Poland) were routinely distilled and dried prior to use. Amines: $p$-toluidine and $p$-anisidine, dimethyl 
and dibenzyl phosphites, and ferrocenecarboxaldehyde (Aldrich, Poznań, Poland) were used as received. NMR spectra were recorded on a Bruker Avance III $600 \mathrm{MHz}$, operated at $600 \mathrm{MHz}$ $\left({ }^{1} \mathrm{H}\right.$ NMR), $150 \mathrm{MHz}\left({ }^{13} \mathrm{C}\right.$ NMR) and $243 \mathrm{MHz}\left({ }^{31} \mathrm{P}\right.$ NMR). Phosphoric acid was used as the external standard for ${ }^{31} \mathrm{P} N \mathrm{NM}$, while ${ }^{1} \mathrm{H}$ and ${ }^{13} \mathrm{C}$ NMR spectra were set on deuterated solvents. Elemental analyses were carried out at the Centre for Molecular and Macromolecular Science of the Polish Academy of Science in Łódź, Poland (2a, 2b, 2d) and in the Laboratory of Molecular Spectroscopy, Faculty of Chemistry, University of Łódź (2c).

\section{Synthesis of Schiff bases 1a-b}

Ferrocenecarboxaldehyde (2.14 g, $10 \mathrm{mmol}$ ) was dissolved in methanol dried over $\mathrm{CaH}_{2}(20-30 \mathrm{~mL})$, and to this solution, amine (10 mmol, $1.07 \mathrm{~g}$ of $p$-toluidine, or $1.23 \mathrm{~g}$ of $p$-anisidine) was added. The mixture was stirred at room temperature for $24 \mathrm{~h}$, then the solvent was evaporated and the residue dried under vacuum to obtain the crude Schiff bases $\mathbf{1 a - b}$, which were crystallized from hexane-ethyl acetate $1: 1,{ }^{12 h}$ and were used as soon as possible for further conversions.

$\boldsymbol{N}$-Ferrocenylidene- $\boldsymbol{p}$-anisidine (1a). ${ }^{\mathbf{1 2 h}}$ Yield 93\% (3.01 g), mp $=107-108{ }^{\circ} \mathrm{C} .{ }^{1} \mathrm{H} \mathrm{NMR}\left(\mathrm{CDCl}_{3}, 600 \mathrm{MHz}\right): \delta 8.33(\mathrm{~s}, \mathrm{CH}=\mathrm{N}, 1 \mathrm{H})$, 7.14 (approx. d, $J=8.6 \mathrm{~Hz}, p-\mathrm{C}_{6} \mathrm{H}_{4}, 2 \mathrm{H}$ ), 6.91 (approx. d, $J=$ $\left.8.6 \mathrm{~Hz}, p-\mathrm{C}_{6} \mathrm{H}_{4}, 2 \mathrm{H}\right), 4.79\left(\mathrm{~s}, \mathrm{H}_{\mathrm{ferr}}, 2 \mathrm{H}\right), 4.46\left(\mathrm{~s}, \mathrm{H}_{\mathrm{ferr}}, 2 \mathrm{H}\right), 4.24(\mathrm{~s}$, $\left.\mathrm{C}_{\mathrm{p}}, 5 \mathrm{H}\right) ; 3.83\left(\mathrm{~s}, \mathrm{OCH}_{3}, 3 \mathrm{H}\right)$.

$\boldsymbol{N}$-Ferrocenylidene-p-toluidine (1b). ${ }^{12 h}$ Yield 94\% (2.85 g), mp $=87-88{ }^{\circ} \mathrm{C} .{ }^{1} \mathrm{H}$ NMR $\left(\mathrm{CDCl}_{3}, 600 \mathrm{MHz}\right): \delta 8.33(\mathrm{~s}, \mathrm{CH}=\mathrm{N}, 1 \mathrm{H})$, 7.18 (approx. d, $J=7.5 \mathrm{~Hz}, p-\mathrm{C}_{6} \mathrm{H}_{4}, 2 \mathrm{H}$ ), 6.91 (approx. d, $J=$ $\left.7.5 \mathrm{~Hz}, p-\mathrm{C}_{6} \mathrm{H}_{4}, 2 \mathrm{H}\right), 4.80\left(\mathrm{~s}, \mathrm{H}_{\text {ferr }}, 2 \mathrm{H}\right), 4.47\left(\mathrm{~s}, \mathrm{H}_{\text {ferr }}, 2 \mathrm{H}\right), 4.24(\mathrm{~s}$, $\left.\mathrm{C}_{\mathrm{p}}, 5 \mathrm{H}\right) ; 2.36\left(\mathrm{~s}, \mathrm{CH}_{3}, 3 \mathrm{H}\right)$.

\section{General procedure for the preparation of aminophosphonates} 2a-d

To a hot solution of an imine $(10 \mathrm{mmol})$ in acetonitrile $(30 \mathrm{~mL})$, a solution of dialkyl phosphite $(10 \mathrm{mmol})$ in acetonitrile $(10 \mathrm{~mL})$ was added, followed by 3-5 drops of trifluoroacetic acid. The obtained solution was heated at $78-80{ }^{\circ} \mathrm{C}$ for $48 \mathrm{~h}$, then evaporated and the residue was chromatographed on silica gel (ethyl acetate-hexane $4: 1$ ). The obtained products were finally purified by crystallization from ethyl acetate-hexane (the suspension of the product in hexane was heated and then hot ethyl acetate was added until dissolution, then filtered, cooled and kept in a freezer for a couple of days). Crystals were collected by suction to give products $\mathbf{2 a - d}$ as dark yellow crystals.

Dimethyl $\quad \mathrm{N}$-(4-methoxyphenyl)amino(ferrocenyl)methylphosphonate (2a). Yield: $2.92 \mathrm{~g}$ (68\%); Mp: $119-120{ }^{\circ} \mathrm{C} .{ }^{1} \mathrm{H}$ NMR (600 MHz, $\mathrm{CDCl}_{3}$ ): $\delta 6.84$ (approx. $\mathrm{d}, J=8.8 \mathrm{~Hz}, p-\mathrm{C}_{6} \mathrm{H}_{4}, 2 \mathrm{H}$ ); 6.78 (approx. d, $\left.J=8.8 \mathrm{~Hz}, p-\mathrm{C}_{6} \mathrm{H}_{4}, 2 \mathrm{H}\right) ; 4.41$ (dd, ${ }^{2} J_{\mathrm{PH}}=16.3$ and $\left.{ }^{3} J_{\mathrm{HH}}=8.4 \mathrm{~Hz}, \mathrm{CHP}, 1 \mathrm{H}\right) ; 4.31-4.29\left(\mathrm{~m}, \mathrm{H}_{\mathrm{ferr}}, 2 \mathrm{H}\right), 4.20-4.18(\mathrm{~m}$, $\left.\mathrm{H}_{\text {ferr }}, 2 \mathrm{H}\right), 4.08\left(\mathrm{~s}, \mathrm{C}_{\mathrm{p}}, 5 \mathrm{H}\right) ; 3.90-3.87(\mathrm{~m}, \mathrm{NH}, 1 \mathrm{H}) ; 3.76\left(\mathrm{~s}, \mathrm{OCH}_{3}\right.$, $3 \mathrm{H}) ; 3.67\left(\mathrm{~d},{ }^{3} J_{\mathrm{PH}}=10.1 \mathrm{~Hz}, \mathrm{POCH}_{3}, 3 \mathrm{H}\right) ; 3.63\left(\mathrm{~d},{ }^{3} \mathrm{~J}_{\mathrm{PH}}=10.4 \mathrm{~Hz}\right.$, $\left.\mathrm{POCH}_{3}, 3 \mathrm{H}\right) .{ }^{13} \mathrm{C} \mathrm{NMR}\left(150 \mathrm{MHz}, \mathrm{CDCl}_{3}\right): \delta 152.9\left(\mathrm{C}_{\text {arom }}\right) ; 141.3(\mathrm{~d}$, $\left.{ }^{3} J_{\mathrm{CP}}=3.5 \mathrm{~Hz}, \mathrm{C}_{\text {arom }}\right) ; 115.0\left(\mathrm{C}_{\text {arom }}\right) ; 85.4\left(\mathrm{C}_{\mathrm{ferr}}\right) ; 68.7\left(\mathrm{C}_{\mathrm{p}}\right) ; 68.5(\mathrm{~d}$, $\left.{ }^{3} J_{\mathrm{CP}}=3.9 \mathrm{~Hz}, \mathrm{C}_{\text {ferr }}\right) ; 68.1\left(\mathrm{C}_{\text {ferr }}\right) ; 67.8\left(\mathrm{C}_{\mathrm{ferr}}\right) ; 65.9\left(\mathrm{~d},{ }^{3} J_{\mathrm{CP}}=2.0 \mathrm{~Hz}\right.$, $\mathrm{C}_{\text {ferr }}$ ); $55.7\left(\mathrm{C}_{\mathrm{arOC}}\right.$ ); 53.8 (d, ${ }^{3} J_{\mathrm{CP}}=6.8 \mathrm{~Hz}$, POC); $53.2 \mathrm{~d},{ }^{3} J_{\mathrm{CP}}=$ $7.4 \mathrm{~Hz}$, POC; $53.0\left(\mathrm{~d},{ }^{1} J_{\mathrm{CP}}=161.2 \mathrm{~Hz}, \mathrm{C}-\mathrm{P}\right) .{ }^{31} \mathrm{P}$ NMR $(243 \mathrm{MHz}$,
$\mathrm{CDCl}_{3}$ ): $\delta$ 24.06. Elem. anal. calcd for $\mathrm{C}_{20} \mathrm{H}_{24} \mathrm{NO}_{4} \mathrm{PFe}: \mathrm{C}, 55.96 ; \mathrm{H}$, 5.64; N, 3.26. Found: C, 55.75; H, 5.50; N, 3.26.

Dimethyl $\quad \boldsymbol{N}$-(4-methylphenyl)amino(ferrocenyl)methylphosphonate (2b). ${ }^{12 \mathrm{j}}$ Yield: $2.15 \mathrm{~g}$ (52\%); Mp: $170-171{ }^{\circ} \mathrm{C}$; $\operatorname{lit}^{12 j}$ 167-169 ${ }^{\circ} \mathrm{C} .{ }^{1} \mathrm{H}$ NMR (600 MHz, $\mathrm{CDCl}_{3}$ ): $\delta 7.06$ (approx. d, $J=$ $8.2 \mathrm{~Hz}, p-\mathrm{C}_{6} \mathrm{H}_{4}, 2 \mathrm{H}$ ); 6.73 (approx. $\mathrm{d}, J=8.2 \mathrm{~Hz}, p-\mathrm{C}_{6} \mathrm{H}_{4}, 2 \mathrm{H}$ ); 4.47 $\left(\mathrm{dd},{ }^{2} J_{\mathrm{PH}}=16.7\right.$ and $\left.{ }^{3} J_{\mathrm{HH}}=8.6 \mathrm{~Hz}, \mathrm{CHP}, 1 \mathrm{H}\right) ; 4.31-4.29\left(\mathrm{~m}, \mathrm{H}_{\text {ferr }}\right.$, $2 \mathrm{H}), 4.20-4.18\left(\mathrm{~m}, \mathrm{H}_{\text {ferr }}, 1 \mathrm{H}\right), 4.18-4.16\left(\mathrm{~m}, \mathrm{H}_{\text {ferr }}, 1 \mathrm{H}\right), 4.07\left(\mathrm{~s}, \mathrm{C}_{\mathrm{p}}\right.$, $5 \mathrm{H}) ; 4.02\left(\mathrm{dd},{ }^{3} J_{\mathrm{PH}}=4.6\right.$ and $\left.{ }^{3} J_{\mathrm{HH}}=8.3 \mathrm{~Hz}, \mathrm{NH}, 1 \mathrm{H}\right) ; 3.67\left(\mathrm{~d},{ }^{3} J_{\mathrm{PH}}\right.$ $\left.=10.3 \mathrm{~Hz}, \mathrm{POCH}_{3}, 3 \mathrm{H}\right) ; 3.62\left(\mathrm{~d},{ }^{3} \mathrm{~J}_{\mathrm{PH}}=10.4 \mathrm{~Hz}, \mathrm{POCH}_{3}, 3 \mathrm{H}\right) ; 2.26$ $\left(\mathrm{s}, \mathrm{CH}_{3}, 3 \mathrm{H}\right) .{ }^{13} \mathrm{C} \mathrm{NMR}\left(150 \mathrm{MHz}, \mathrm{CDCl}_{3}\right): \delta 144.8\left(\mathrm{~d},{ }^{3} J_{\mathrm{CP}}=5.9 \mathrm{~Hz}\right.$, $\left.\mathrm{C}_{\text {arom }}\right) ; 129.9\left(\mathrm{C}_{\text {arom }}\right) ; 127.8\left(\mathrm{C}_{\text {arom }}\right) ; 113.7\left(\mathrm{C}_{\text {arom }}\right) ; 85.4\left(\mathrm{~d},{ }^{3} J_{\mathrm{CP}}=\right.$ $\left.6.9 \mathrm{~Hz}, \mathrm{C}_{\mathrm{ferr}}\right) ; 68.7\left(\mathrm{C}_{\mathrm{p}}\right) ; 68.5\left(\mathrm{~d},{ }^{3} J_{\mathrm{CP}}=4.3 \mathrm{~Hz}, \mathrm{C}_{\mathrm{ferr}}\right) ; 68.1\left(\mathrm{C}_{\mathrm{ferr}}\right)$; $67.8\left(\mathrm{C}_{\mathrm{ferr}}\right) ; 65.9\left(\mathrm{~d},{ }^{3} J_{\mathrm{CP}}=2.8 \mathrm{~Hz}, \mathrm{C}_{\text {ferr }}\right) ; 53.8\left(\mathrm{~d},{ }^{3} J_{\mathrm{CP}}=7.3 \mathrm{~Hz}\right.$, POC); $53.2 \mathrm{~d},{ }^{3} J_{\mathrm{CP}}=7.0 \mathrm{~Hz}$, POC; 52.1 (d, $\left.{ }^{1} J_{\mathrm{CP}}=160.9 \mathrm{~Hz}, \mathrm{C}-\mathrm{P}\right)$; $20.4\left(\mathrm{C}_{\mathrm{ar}} \mathrm{C}\right) .{ }^{31} \mathrm{P}$ NMR $\left(243 \mathrm{MHz}, \mathrm{CDCl}_{3}\right): \delta$ 24.00. Elem. anal. calctd for $\mathrm{C}_{20} \mathrm{H}_{24} \mathrm{NO}_{3}$ PFe: C, 58.13; H, 5.85; N, 3.39. Found: C, $57.91 ; \mathrm{H}, 5.67 ; \mathrm{N}, 3.35$.

Dibenzyl $\quad \boldsymbol{N}$-(4-methoxyphenyl)amino(ferrocenyl)methylphosphonate (2c). Yield: $3.02 \mathrm{~g}$ (52\%); Mp: $106-107{ }^{\circ} \mathrm{C} .{ }^{1} \mathrm{H}$ NMR (600 MHz, $\left.\mathrm{CDCl}_{3}\right): \delta 7.30-7.29(\mathrm{~m}, \mathrm{PhH}, 3 \mathrm{H}) ; 7.28-7.27(\mathrm{~m}$, PhH, 3H); 7.23-7.21 (m, PhH, 2H); 7.20-7.18 (m, PhH, 2H); 6.81 (approx. d, $J=9.0 \mathrm{~Hz}, p-\mathrm{C}_{6} \mathrm{H}_{4}, 2 \mathrm{H}$ ); 6.76 (approx. $\mathrm{d}, J=9.0 \mathrm{~Hz}, p$ $\mathrm{C}_{6} \mathrm{H}_{4}, 2 \mathrm{H}$ ); 5.01 and 4.87 (part of $\mathrm{ABX}$ system, ${ }^{3} J_{\mathrm{PH}}=6.9,{ }^{3} J_{\mathrm{PH}}=$ 8.1 and ${ }^{2} J_{\mathrm{HH}}=11.7 \mathrm{~Hz}, \mathrm{OCHPh}, 1 \mathrm{H}$ ); 4.92 and 4.85 (part of ABX system, ${ }^{3} J_{\mathrm{PH}}=7.1,{ }^{3} J_{\mathrm{PH}}=8.1$ and ${ }^{2} J_{\mathrm{HH}}=11.8 \mathrm{~Hz}$, OCHPh, $\left.1 \mathrm{H}\right)$; $4.48\left(\mathrm{dd},{ }^{2} J_{\mathrm{PH}}=16.1\right.$ and $\left.{ }^{3} J_{\mathrm{HH}}=8.6 \mathrm{~Hz}, \mathrm{CHP}, 1 \mathrm{H}\right) ; 4.29-4.27(\mathrm{~m}$, $\left.\mathrm{H}_{\text {ferr }}, 2 \mathrm{H}\right), 4.20-4.18$ (m, $\left.\mathrm{H}_{\text {ferr }}, 1 \mathrm{H}\right), 4.17-4.15$ (m, $\left.\mathrm{H}_{\text {ferr }}, 1 \mathrm{H}\right), 4.05$ $\left(\mathrm{s}, \mathrm{C}_{\mathrm{p}}, 5 \mathrm{H}\right) ; 3.92\left(\mathrm{dd},{ }^{3} J_{\mathrm{PH}}=5.4\right.$ and $\left.{ }^{3} J_{\mathrm{HH}}=8.3 \mathrm{~Hz}, \mathrm{NH}, 1 \mathrm{H}\right) ; 3.77$ $\left(\mathrm{s}, \mathrm{OCH}_{3}, 3 \mathrm{H}\right) .{ }^{13} \mathrm{C} \mathrm{NMR}\left(150 \mathrm{MHz}, \mathrm{CDCl}_{3}\right)$ : $\delta 152.9\left(\mathrm{C}_{\text {arom }}\right) ; 141.4$ $\left(\mathrm{d},{ }^{3} J_{\mathrm{CP}}=5.6 \mathrm{~Hz}, \mathrm{C}_{\text {arom}}\right) ; 136.5\left(\mathrm{~d},{ }^{2} J_{\mathrm{CP}}=5.7 \mathrm{~Hz}, \mathrm{C}_{\text {arom }}\right) ; 136.4$ (d, $\left.{ }^{2} J_{\mathrm{CP}}=6.2 \mathrm{~Hz}, \mathrm{C}_{\text {arom}}\right) ; 128.4\left(\mathrm{~d},{ }^{3} J_{\mathrm{CP}}=4.3 \mathrm{~Hz}, \mathrm{C}_{\text {arom }}\right) ; 128.2(\mathrm{~d}$, $\left.{ }^{3} J_{\mathrm{CP}}=5.3 \mathrm{~Hz}, \mathrm{C}_{\text {arom }}\right) ; 128.0\left(\mathrm{C}_{\text {arom }}\right) ; 127.9\left(\mathrm{C}_{\text {arom }}\right) ; 115.2\left(\mathrm{C}_{\text {arom }}\right)$; $115.0\left(\mathrm{C}_{\text {arom }}\right) ; 85.4\left(\mathrm{C}_{\mathrm{ferr}}\right) ; 68.8\left(\mathrm{C}_{\mathrm{p}}\right) ; 68.5\left(\mathrm{~d},{ }^{3} J_{\mathrm{CP}}=6.9 \mathrm{~Hz}, \mathrm{POC}\right)$; $68.1\left(\mathrm{C}_{\mathrm{ferr}}\right) ; 68.0\left(\mathrm{~d},{ }^{3} J_{\mathrm{CP}}=7.4 \mathrm{~Hz}, \mathrm{POC}\right) ; 67.9\left(\mathrm{C}_{\mathrm{ferr}}\right) ; 66.0\left(\mathrm{C}_{\mathrm{ferr}}\right)$; $55.8\left(\mathrm{C}_{\mathrm{ar}} \mathrm{OC}\right) ; 53.5$ (d, $\left.{ }^{1} J_{\mathrm{CP}}=159.5 \mathrm{~Hz}, \mathrm{C}-\mathrm{P}\right) .{ }^{31} \mathrm{P}$ NMR $(243 \mathrm{MHz}$, $\mathrm{CDCl}_{3}$ ): $\delta$ 22.48. Elem. anal. calctd for $\mathrm{C}_{32} \mathrm{H}_{32} \mathrm{FeNO}_{4} \mathrm{P}: \mathrm{C}, 66.10$; H, 5.55; N, 2.41. Found: C, 65.88; H, 5.57; N, 2.40.

Dibenzyl $\quad \boldsymbol{N}$-(4-methylphenyl)amino(ferrocenyl)methylphosphonate (2d). Yield: $2.94 \mathrm{~g}$ (52\%); Mp: $120-121{ }^{\circ} \mathrm{C} .{ }^{1} \mathrm{H}$ NMR (600 MHz, $\mathrm{CDCl}_{3}$ ): $\delta$ 7.29-7.25 (m, PhH, 6H); 7.22-7.18 (m, $\mathrm{PhH}, 4 \mathrm{H}$ ); 7.03 (approx. d, $J=7.8 \mathrm{~Hz}, p-\mathrm{C}_{6} \mathrm{H}_{4}, 2 \mathrm{H}$ ); 6.71 (approx. d, $J=7.8 \mathrm{~Hz}, p-\mathrm{C}_{6} \mathrm{H}_{4}, 2 \mathrm{H}$ ); 5.01 (part A of AMX system, ${ }^{3} \mathrm{~J}_{\mathrm{PH}}=6.3$ and ${ }^{2} J_{\mathrm{HH}}=11.3 \mathrm{~Hz}, \mathrm{OCHPh}, 1 \mathrm{H}$ ); 4.91 (part A of ABX system, ${ }^{3} J_{\mathrm{PH}}$ $=6.7$ and ${ }^{2} J_{\mathrm{HH}}=11.5 \mathrm{~Hz}$, OCHPh, $\left.1 \mathrm{H}\right) ; 4.87-4.83(\mathrm{~m}, \mathrm{OCHPh}$, $2 \mathrm{H}) ; 4.54\left(\mathrm{dd},{ }^{2} J_{\mathrm{PH}}=15.4\right.$ and $\left.^{3} J_{\mathrm{HH}}=8.6 \mathrm{~Hz}, \mathrm{CHP}, 1 \mathrm{H}\right) ; 4.31-4.29$ (m, $\left.\mathrm{H}_{\text {ferr }}, 2 \mathrm{H}\right), 4.21-4.19\left(\mathrm{~m}, \mathrm{H}_{\text {ferr }}, 1 \mathrm{H}\right), 4.18-4.16\left(\mathrm{~m}, \mathrm{H}_{\mathrm{ferr}}, 1 \mathrm{H}\right)$, 4.07 (s, $\left.\mathrm{C}_{\mathrm{p}}, 5 \mathrm{H}\right)$; 4.04-4.01 (m, NH, $\left.1 \mathrm{H}\right) ; 2.27$ (s, $\left.\mathrm{CH}_{3}, 3 \mathrm{H}\right) .{ }^{13} \mathrm{C}$ $\operatorname{NMR}\left(150 \mathrm{MHz}, \mathrm{CDCl}_{3}\right): \delta 144.9\left(\mathrm{~d},{ }^{3} J_{\mathrm{CP}}=5.4 \mathrm{~Hz}, \mathrm{C}_{\text {arom }}\right) ; 136.5(\mathrm{~d}$, $\left.{ }^{2} J_{\mathrm{CP}}=5.6 \mathrm{~Hz}, \mathrm{C}_{\text {arom }}\right) ; 136.3\left(\mathrm{~d},{ }^{2} J_{\mathrm{CP}}=6.2 \mathrm{~Hz}, \mathrm{C}_{\text {arom }}\right) ; 129.9\left(\mathrm{C}_{\text {arom }}\right)$; $128.4\left(\mathrm{~d},{ }^{3} J_{\mathrm{CP}}=4.5 \mathrm{~Hz}, \mathrm{C}_{\text {arom }}\right) ; 128.2\left(\mathrm{~d},{ }^{3} J_{\mathrm{CP}}=6.6 \mathrm{~Hz}, \mathrm{C}_{\text {arom}}\right)$; $128.0\left(\mathrm{C}_{\text {arom }}\right) ; 127.9\left(\mathrm{C}_{\text {arom }}\right) ; 127.8\left(\mathrm{C}_{\text {arom }}\right) ; 114.0\left(\mathrm{C}_{\text {arom }}\right) ; 85.5(\mathrm{~d}$, $\left.{ }^{2} J_{\mathrm{CP}}=7.0 \mathrm{~Hz}, \mathrm{C}_{\mathrm{ferr}}\right) ; 68.8\left(\mathrm{C}_{\mathrm{p}}\right) ; 68.5\left(\mathrm{~d},{ }^{3} J_{\mathrm{CP}}=7.0 \mathrm{~Hz}, \mathrm{POC}\right) ; 68.1$ $\left(\mathrm{C}_{\mathrm{ferr}}\right) ; 68.0\left(\mathrm{~d},{ }^{3} J_{\mathrm{CP}}=7.4 \mathrm{~Hz}, \mathrm{POC}\right) ; 67.8\left(\mathrm{C}_{\mathrm{ferr}}\right) ; 66.1\left(\mathrm{C}_{\mathrm{ferr}}\right) ; 52.7(\mathrm{~d}$, $\left.{ }^{1} J_{\mathrm{CP}}=159.2 \mathrm{~Hz}, \mathrm{C}-\mathrm{P}\right) ; 20.4\left(\mathrm{C}_{\mathrm{ar}} \mathrm{OC}\right) .{ }^{31} \mathrm{P} \mathrm{NMR}\left(243 \mathrm{MHz}, \mathrm{CDCl}_{3}\right)$ : $\delta$ 22.36. Elem. anal. calctd for $\mathrm{C}_{32} \mathrm{H}_{32} \mathrm{FeNO}_{3} \mathrm{P}: \mathrm{C}, 67.97 ; \mathrm{H}, 5.70 ; \mathrm{N}$, 2.48. Found: C, 68.01; H, 5.84; N, 4.42 . 


\section{Plant growth test of new synthesized compounds}

The plant growth test of aminophosphonates 2a-d was performed under laboratory conditions, following the OECD 208 Guideline for Terrestrial Plants Growth Test for oat (Avena sativa) as a monocotyledonous plant and radish (Raphanus sativus L. subvar. radicula Pers.), a dicotyledonous plant. ${ }^{13}$

According to the mentioned OECD 208 standard, the plant growth tests of compounds $\mathbf{2 a - d}$ were carried out in sandy soil having the following parameters: granulometric composition of soil- $77 \%$ sand, $16 \%$ dust and loam, organic carbon content of approx. $1.6 \%, \mathrm{pH}(\mathrm{KCl})$ equal to 6.6 .

Tests were carried out in polypropylene pots (diameter of 90 $\mathrm{mm}$ and capacity of $300 \mathrm{~cm}^{3}$ ), which were filled with the control soil or with the soil mixed with the tested compounds 2a-d added at the following concentrations: 1, 10, 100, 200, 400, 800 and $1000 \mathrm{mg} \mathrm{kg}^{-1}$ of soil dry weight. Each concentration was done in triplicate (3 pots for oat, 3 pots for common radish).

Twenty seeds of each of the selected plant species were sown into the soil. Seeds originated from the same source. Plants were grown for 14 days under controlled conditions: a constant humidity content at the level required for the plants $(70 \%$ field water capacity), temperature $\left(20 \pm 2{ }^{\circ} \mathrm{C}\right)$, constant light intensity (7000 lux), were maintained in the system for $16 \mathrm{~h}$ per day and $8 \mathrm{~h}$ per night.

The evaluation of the phytotoxicity of the studied aminophosphonates $\mathbf{2 a - d}$ at applied concentrations was made by comparing the germination and dry weight of the control plants sprouts (seedlings) with the germination and dry and fresh plant sprouts grown in the soil with an admixture of given amounts of the tested compounds. In order to determine the growth inhibition of the roots and shoots of selected plants, the height of the shoot and length of root were measured as described by Wang et al. ${ }^{\mathbf{1 4 a}}$ The length of plants was defined as the length from the tip of the longest leaf to the base of the culms, while root length was measured from the tip of the longest root to the root-shoot junction.

The inhibition ratio was calculated according to the method given by Pawlowska and Biczak, ${ }^{14 b}$ namely, length in the control group - length in the treatment group $\times 100 \% /$ length of the control group.

Effective concentration $\mathrm{EC}_{50}$ for fresh plant matter was calculated using GraphPad Prism software (Version 7, GraphPad Software, Inc., La Jolla, CA 92037, USA).

The dry weights of tested plants were measured after drying at $75{ }^{\circ} \mathrm{C}$ until constant weight.

Values of the no observed effect concentration (NOEC) and the lowest observed effect concentration (LOEC) of the compounds under study, 2a-d, were determined. The visual evaluation of the phytotoxicity of aminophosphonates $\mathbf{2 a - d}$ at applied concentrations was performed by digital photography. Obtained pictures were analyzed in terms of any type of damage to the tested plants, such as their growth inhibition, chlorosis, and necrosis. Tests were carried out three times for each sample.

\section{Pigment assay}

The photosynthetic pigments content was determined according to the method reported by Oren et al. ${ }^{15}$ Briefly, $200 \mathrm{mg}$ of fresh leaves were thoroughly homogenized in $20 \mathrm{~mL}$ of $80 \%$ acetone by means of a cooled mortar, and centrifuged. The content of chlorophyll a, chlorophyll $\mathrm{b}$ and carotenoids was calculated based on the absorbance at wavelength 470, 647 and $664 \mathrm{~nm}$. The contents of photosynthetic pigments were expressed in $\mathrm{mg} \mathrm{g}^{-1}$ of dry weight.

\section{Microtox® toxicity assay}

The detailed procedure for the Microtox Toxicity Assay has been described previously by Lewkowski et al. ${ }^{\mathbf{1 6}}$ The method is based on the analysis of the light emission reduction of luminescent bacteria (Vibrio fischeri) under toxic stress. The tests were carried out in a Microtox® M500 analyzer, according to the 1992 Microtox® Manual. The Microtox® Solid-Phase Test (MSPT) was adapted from the report of Doe et $a .^{17}$

The MSPT procedure allowed the test organisms to come into direct contact with the solid sample in an aqueous suspension of the test sample. Thus, it was possible to detect the toxicity due to the insoluble solids that were not in the solution. All materials and reagents were purchased from MODERNWATER (New Castle, DE, USA). Toxicity was determined by using the marine luminescent bacterium, Vibrio fischeri, naturally adapted to a saline environment. Briefly, the bacteria were regenerated with $1 \mathrm{~mL}$ of reconstitution solution $(0.01 \%)$ and were placed in the reagent well of the Microtox®. A suspension of $7 \mathrm{~g}$ of the sediment was prepared in $35 \mathrm{~mL}$ of a Solid Phase Diluent (3.5\% $\mathrm{NaCl})$ and was magnetically stirred for $10 \mathrm{~min}$. Then, a series of dilutions were made and bacteria (approx. $1 \times 10^{6}$ cell per $\mathrm{mL}$ per assay) were exposed to these dilutions and to a blank (3.5\% NaCl solution) for $20 \mathrm{~min}$. After filtration, the light output of the supernatant containing exposed bacteria was measured after $5 \mathrm{~min}$ with a Microtox® Analyzer 500. Inhibition was calculated as the concentration of compound loaded to sediment $\left(\mathrm{mg} \mathrm{kg}^{-1}\right)$ that caused a $50 \%$ reduction in the light emitted by the bacteria, and $\mathrm{EC}_{50}$ along with $95 \%$ confidence limit were determined by the software provided with the Analyzer.

\section{Ostracod test kit}

The ecotoxicity evaluation of the synthesized compounds was performed in a short term contact test using the Ostracodtoxkit $\mathrm{F}^{\mathrm{TM}}$ provided by MicroBiotests Inc. (Gent, Belgium). This direct sediment contact bioassay was performed in multiwell test plates using neonates of the benthic ostracod crustacean Heterocypris incongruens hatched from cysts. ${ }^{18}$

After 6 days of contact with the sediment (or soil), the percentage mortality and the growth of the crustaceans were determined and compared to the results obtained in a nontreated reference sediment (soil). Briefly, according to the manual of the Ostracodtoxkit test, the cysts (Heterocypris incongruens) were transferred into a Petri dish filled with $10 \mathrm{~mL}$ of standard fresh water (reconstituted water) and were 
incubated at $25{ }^{\circ} \mathrm{C}$ for $52 \mathrm{~h}$ under continuous illumination (approx. 3000-4000 lux). After $48 \mathrm{~h}$ of cyst incubation, prefeeding of the freshly hatched ostracods was performed with algae (spirulina-powder) provided in the test kit. After hatching, before feeding with algal food suspension, the length measurements of the ostracod neonates were done. Algae (Selenastrum capricornutum) used as feed in the test plate was reconstituted according to the manufacturer's procedures. Each well of a test plate was filled in the following order: $2 \mathrm{~mL}$ standard freshwater, $2500 \mu \mathrm{L}$ of sediment (soil) treated and non-treated for comparison (blank), $2 \mathrm{~mL}$ already prepared algal suspension, 10 ostracods. The test plates were covered with Parafilm ${ }^{\circledR}$ and closed with a lid. Then multi wall plates were incubated at $25{ }^{\circ} \mathrm{C}$ in darkness for 6 days. After 6 days of exposure, the ostracods were recovered from the multiwells to determine the percentage mortality. To calculate the growth inhibition of surviving organisms, their length measurements were determined. The mortality of test organisms was determined in six replicates. The measurement of length was carried out by means of a micrometric strip placed on the bottom of a glass microscope plate. Growth inhibition (GI) of $H$. incongruens in the test sediment was calculated as follows:

$$
\text { Growth inhibition } \%=100-\frac{\text { growth in test sed. }}{\text { growth in ref. sed. }} \times 100
$$

\section{Statistical analysis}

The significance of the obtained results was evaluated using the analysis of variance (ANOVA). The least significant difference (LSD) values at a confidence level of $95 \%$ were computed using the Tukey test. Moreover, the mean standard deviations were determined and plotted in diagrams.

\section{Results and discussion}

\section{Synthesis of studied Schiff bases $1 \mathrm{a}-\mathrm{b}$ and aminophosphonates 2a-d}

Schiff bases 1a-b were synthesized following the previously published procedure, by simply mixing ferrocenecarboxaldehyde with the appropriate amine in dry methanol and

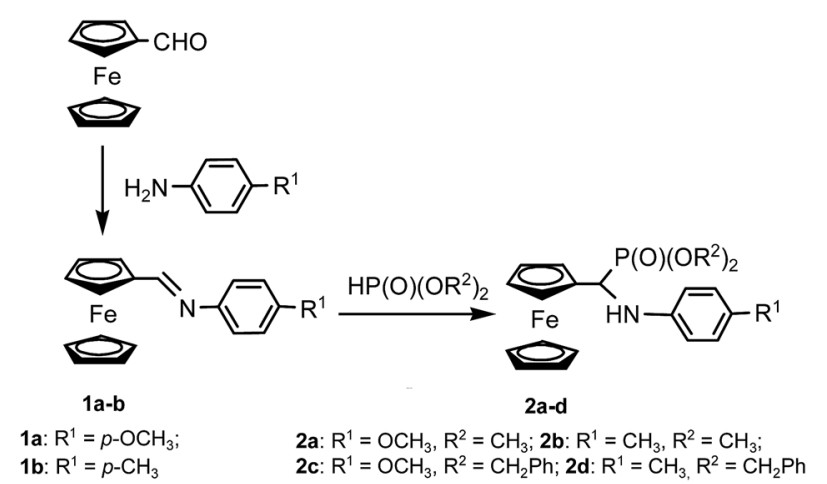

Scheme 1 Synthesis of $N$-arylamino(ferrocenyl)methylphosphonates $2 a-d$. stirring them at room temperature for 24 hours. ${ }^{\mathbf{1 2 h}}$ This procedure gave imines $\mathbf{1 a}-\mathbf{b}$ in over $90 \%$ yield. Their identities were confirmed by melting point measurement and $1 \mathrm{H}$ NMR spectral data, which were compared with the previously obtained data. ${ }^{12 h}$ The ${ }^{1} \mathrm{H}$ NMR spectra showed the diagnostic singlet at around $8.3 \mathrm{ppm}$, corresponding to a proton of the azomethine group $(-\mathrm{CH}=\mathrm{N}-)$ and the characteristic set of signals of monosubstituted ferrocene - two singlets at 4.7 and $4.5 \mathrm{ppm}$ of a substituted ring and the third, at $c a .4 .2 \mathrm{ppm}$, corresponding to unsubstituted cyclopentadiene.

Ferrocene-derived aminophosphonates 2a-d were synthesized by the addition of methyl or benzyl phosphite to the azomethine bond of the corresponding Schiff bases 1a-b in acetonitrile. The conversion was monitored by means of TLC and ${ }^{31} \mathrm{P}$ NMR, and after 48 hours the reaction was complete. The resulting crude aminophosphonates $\mathbf{2 a - d}$ were purified by column chromatography followed by crystallization. They were obtained in $50-70 \%$ yields. (Scheme 1). The aminophosphonate 2b has already been described by us while testing the Kabachnik-Fields reaction in non-classical conditions; ${ }^{12 j}$ the others, i.e. 2a and 2c-d, to our best knowledge, have never been described. Their identity has been verified by means of ${ }^{1} \mathrm{H},{ }^{13} \mathrm{C}$ and ${ }^{31} \mathrm{P}$ NMR spectroscopy. The ${ }^{1} \mathrm{H}$ NMR spectra of aminophosphonates 2a-d showed diagnostic signals typical of aminophosphonates, i.e. a doublet of doublets attributable to a proton from a HCP group, which couples with a phosphorus nucleus and with a proton of a $\mathrm{NH}$ group. Sets of signals were also observed, which are typical for monosubstituted ferrocenes, i.e. two multiples corresponding to protons of a substituted ring between 4 and $4.5 \mathrm{ppm}$ and a singlet of 5 protons of an unsubstituted ring. Two doublets of OMe groups linked to phosphorus (2a-b) and two ABX systems of benzyloxy groups (2c-d) were also observed.

${ }^{13} \mathrm{C}$ NMR spectra of aminophosphonates 2a-d showed a doublet at around $50 \mathrm{ppm}$ having a coupling constant around $150 \mathrm{~Hz}$ corresponding to a CP bond, which is characteristic of aminophosphonates. Ferrocenyl rings also gave characteristic signals of their carbons: a signal at $c a .85 \mathrm{ppm}$ of a quaternary carbon coupled with phosphorus, a sharp signal of a $\mathrm{C}_{\mathrm{p}}$ ring as well as doublets attributed to carbons neighboring an aminomethylphosphonic group (at around 70-65 ppm). Spectra of aminophosphonates $2 \mathbf{2 a}-\mathbf{d}$ are shown in ESI, Fig. S1-S14. $\dagger$

The purity of prepared compounds $\mathbf{2 a - d}$ was confirmed by the elemental analysis and melting point measurements.

\section{Ecotoxicological activity}

It is commonly known that natural amino acid analogues, substituted $\alpha$-aminophosphonate derivatives, are crucial intermediates in the synthesis of various biologically active compounds, which have found wide range applications mostly in medicinal chemistry. Besides the diverse biological activities like enzyme inhibitors, antibiotics, or anticancer agents, substituted $\alpha$-aminophosphonate derivatives have stimulated great interest as antiviral and antifungal agents and they have been extensively used as insecticides and herbicides. ${ }^{\mathbf{1 9 - 2 3}}$ Therefore, considering the biological values and possibilities in 
Table 1 Effect of $2 a-d$ on the shoot height, root length and fresh matter of oat seedlings and common radish plant (mean \pm SD, $n=15)$. $x$ means not measured (no shoot or root to measure)

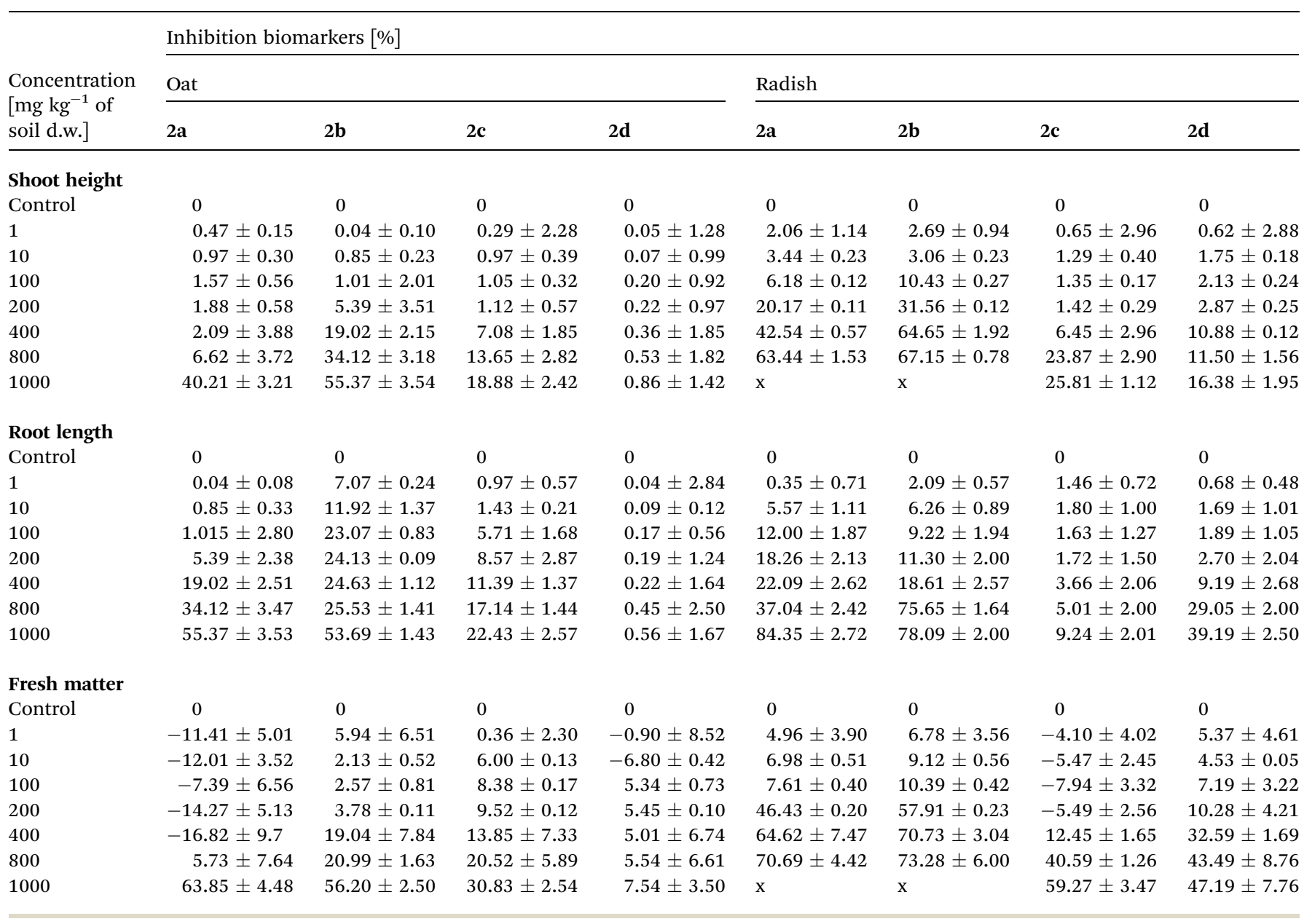

the chemical modification of $\alpha$-amino-phosphonates, the growing concern and the development of new organophosphorus compounds are still of great interest. ${ }^{24-30}$

\section{Plant growth test - germination, growth inhibition, dry and fresh matter}

To evaluate the impact of the tested substances on selected plants, the Plant Growth Test according to OECD 208 Standard has been used as a representative, reliable and well accepted method. It has already been successfully used by the authors to evaluate the toxicity effect of such substances like ionic liquids, thiophene-derived aminophosphonic derivatives or furanderived aminophosphonic acids, $\mathrm{N}$-aryl furaldimines and 5 nitrofuraldimine. ${ }^{31-33}$

The percentage growth inhibition (GI\%) of the shoot and root of examined plants treated with samples of ferrocenederived aminophosphonates $\mathbf{2 a - d}$ are presented in Table 1 . The percentage growth inhibition (GI\%) of shoots for both radish and oat seedlings increased with growing concentration of examined samples 2a-d in soil. Comparing the percentage growth inhibition of oat seedlings for all tested compounds, it was observed that dimethyl aminophosphonates $\mathbf{2 a}$ and $\mathbf{2 b}$ much more negatively affect the growth of this plant, when compared to their dibenzyl analogues $\mathbf{2 c}$ and $\mathbf{2 d}$ (Table 1). The growth inhibition values of compounds $2 \mathbf{a}$ and $2 \mathbf{b}$ were 40 and $55 \%$ respectively, and the higher impact was revealed for the aminophosphonate $\mathbf{2 b}$. Compound $\mathbf{2 c}$ at the highest concentration, i.e. $1000 \mathrm{mg}$ per $\mathrm{kg}$ of soil dry weight, caused the inhibition effect at the level of $19 \%$. The percentage growth inhibition of oat for dibenzyl $\mathrm{N}$-(4-methylphenyl)amino-(ferrocenyl)methylphosphonate $\mathbf{2 d}$, even at the highest applied concentration, did not exceed $1 \%$; therefore, this compound is considered non-toxic to the upper, green part of the oat seedlings. It is worth mentioning that $N$-(4-methylphenyl)amino(ferrocenyl)methylphosphonate $\mathbf{2 b}$ is over 40 times more toxic to oat shoots when compared to the dibenzyl analogue $2 \mathbf{d}$ (for 400, 800 and $1000 \mathrm{mg} \mathrm{kg}^{-1}$ ). Comparing the samples $2 \mathrm{a}$ and $\mathbf{2 c}$, it was noticed that the dimethyl ester $\mathbf{2 a}$ was almost two times more toxic (at the highest concentration, $1000 \mathrm{mg} \mathrm{kg}^{-1}$ ).

The above findings suggest that ferrocene-derived dimethyl aminophosphonates are much more harmful to oat than dibenzyl aminophosphonates, regardless of the methyl or methoxy substitution of the phenyl ring. 
The tested compounds have shown a considerably higher negative impact on the shoot of the radish, as compared to that of oat. The most harmful compounds were dimethyl aminophosphonates $\mathbf{2 a}$ and $\mathbf{2} \mathbf{b}$, as in the case of the oat. At the concentration of $1000 \mathrm{mg}$ per $\mathrm{kg}$ of soil, total inhibition of the radish shoot was noticed. At the concentration of $800 \mathrm{mg} \mathrm{kg}^{-1}$ of soil, the percentage growth inhibition was measurable and reached 63 and $67 \%$ for samples $2 \mathrm{a}$ and $2 \mathbf{b}$, respectively.

It is worth noting that these values were higher when compared to the GI\% of the oat shoot. At the concentration of $800 \mathrm{mg} \mathrm{kg}^{-1}$ of soil, the aminophosphonate $2 \mathrm{a}$ was almost 10 times more toxic for radish than for oat seedlings, while the toxicity value of the compound $\mathbf{2 b}$ was only two times higher for radish than for oat.

The percentage growth inhibition values of sample 2c for both plants were comparable, and sample 2d exhibited a much stronger negative impact on the green parts of the radish to finally reach $16 \%$ of the GI value at the highest concentration.

The percentage growth inhibition of the oat and radish root increased with the increasing concentration of the examined aminophosphonates in soil, similar to the case of the GI\% of the shoot. Dimethyl esters $\mathbf{2 a}$ and $\mathbf{2 b}$ caused much higher inhibition when compared to their dibenzyl analogues. The values of GI\% of both mentioned substances for oat at a concentration $1000 \mathrm{mg} \mathrm{kg}^{-1}$ of soil were almost the same and reached $c a .55 \%$. At the same concentration, compounds $2 \mathrm{a}$ and $\mathbf{2 b}$ caused more harmful effects on the growth of the radish root and were 84 and $78 \%$, respectively.

Aminophosphonates 2c and 2d were less toxic for root growth when compared to $\mathbf{2 a}$ and $\mathbf{2 b}$. The compound $\mathbf{2 d}$ was almost non-toxic for the oat root, and this observation coincides with the results of GI\% of shoots, where only $1 \%$ of inhibition was noticed. However, its toxic effect against radish roots is significant as its GI\% value reached 39\%. Based on the obtained results concerning the growth inhibition of the oat root and shoot for the aminophosphonate $\mathbf{2 d}$, it can be concluded that this compound is totally harmless to this plant. In contrast, the radish was revealed as the more sensitive plant to compound 2d, when compared to oat seedlings, where the roots were especially less resistant.

The percentage growth inhibition (GI\%) values of dibenzyl $N$-(4-methoxyphenyl)-amino(ferrocenyl)methylphosphonate 2c for roots were slightly surprising, as the value for oat reached $22 \%$, whereas for radish roots, this value was only $9 \%$. This shows that the aminophosphonate $2 \mathrm{c}$ is more toxic to oat roots than to radish roots. Percentage growth inhibition coincides with the $\mathrm{EC}_{50}$ values of oat shoots (Fig. 1).

The toxicity of chemicals is usually expressed in terms of the dosage that gives a $50 \%$ effect in the response (such as soil respiration or growth of a plant e.g. root length), compared to the control. The effect can be either an increase or a decrease in response, where the decrease is the effective concentration of the tested sample, and the increase is demonstrated toxicity. Generally, values of effective concentration $\mathrm{EC}_{50}$ for each tested compound was lower for radish, compared to oat seedlings.

Since compound 2d shows the total lack of toxicity toward oat, the value of $\mathrm{EC}_{50}$ was immeasurable. For comparison, the lowest $\mathrm{EC}_{50}$ value given by dimethyl aminophosphonate $\mathbf{2 b}$ (Fig. 1a) corresponds to a high value of the GI\% of oat shoot. The same relationship has been noticed between values of $\mathrm{EC}_{50}$ and the growth inhibition of the root length (Fig. 1b) $E_{50}$ values of compounds $\mathbf{2 a}$ and $\mathbf{2 b}$ were much lower for both shoots and roots of both plants, compared to $\mathrm{EC}_{50}$ values of aminophosphonates 2c-d. Moreover, the aminophosphonate

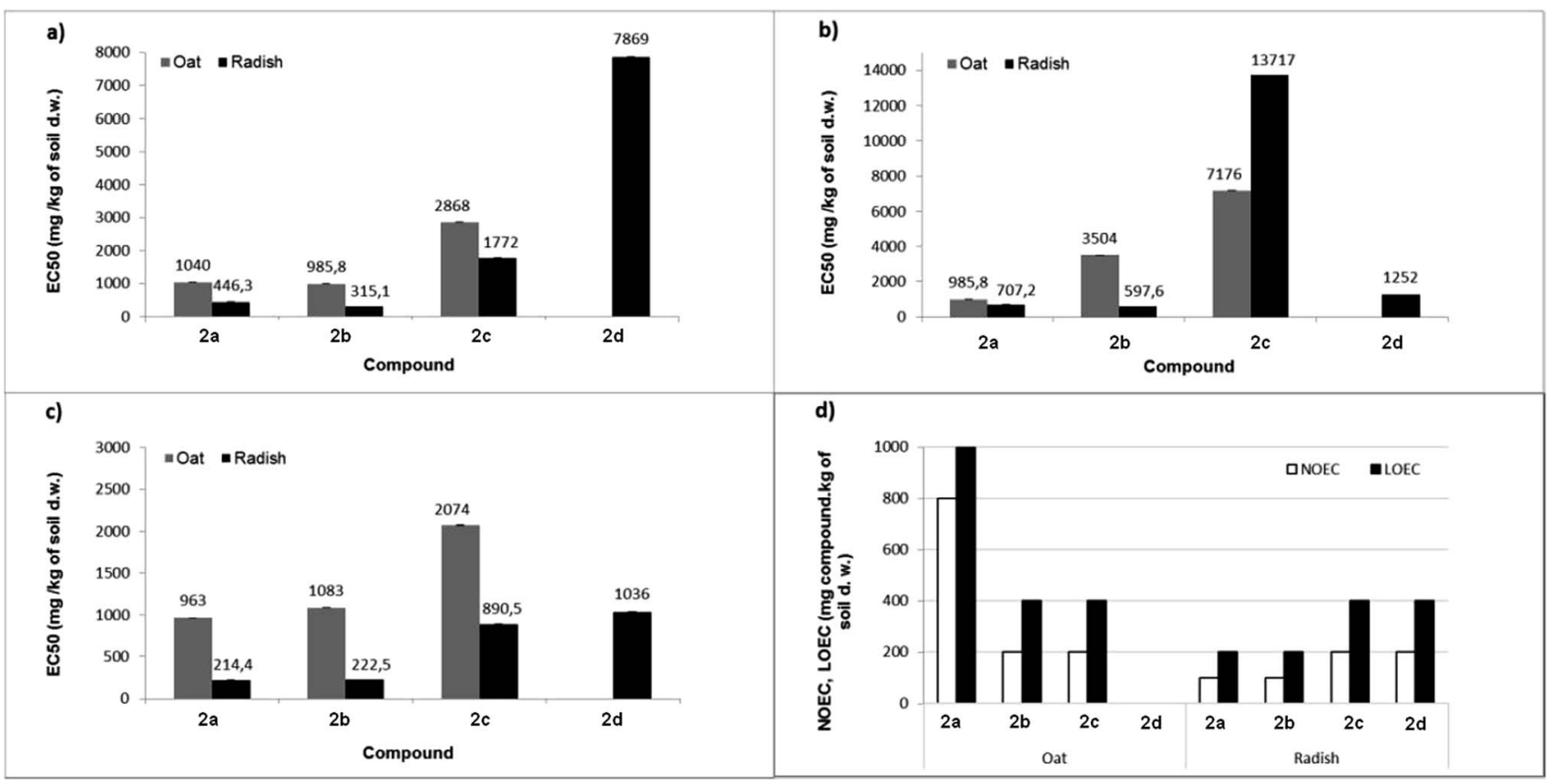

Fig. 1 The $\mathrm{EC}_{50}$ values of the growth inhibition of shoot (a), root (b) and fresh matter (c), as well as NOEC and LOEC values related to fresh matter (d) following exposure to tested compounds. 
2b is slightly more toxic for the shoots of both plants. Certainly, aminophosphonates $\mathbf{2 a - b}$ are generally more harmful to the radish.

$\mathrm{EC}_{50}$ values calculated for fresh matter of both plants was in the following order: $\mathbf{2 a}<\mathbf{2} \mathbf{b}<\mathbf{2 c}<\mathbf{2 d}$. Dimethyl aminophosphonates $\mathbf{2} \mathbf{a}-\mathbf{b}$ have shown the strongest inhibition effect on the content of fresh matter; the same tendency was observed in the case of the growth inhibition of shoot or root.

The dibenzyl analogues $\mathbf{2 c}$ and $\mathbf{2 d}$ exhibited much less harmful effects on the tested plants. Considering the obtained results, it has been concluded that all investigated compounds have a much stronger influence on the fresh matter of the radish as compared to oat seedlings. The lowest effects of concentration values were noticed for compound $\mathbf{2 a}$, namely 963 and $214 \mathrm{mg} \mathrm{kg}^{-1}$ of soil dry weight for oat and radish, respectively. For comparison, the lack of toxicity against oat was

Table 2 Average changes (mean of three replicates) in the germination of oat (Avena sativa) and common radish (Raphanus sativus) treated with $2 a-d$. Least significant difference for samples $\left(L_{S} D_{S}\right)$ and concentration $\left(\mathrm{LSD}_{\mathrm{C}}\right)$ are given for each tested parameter. \% Germination refers to the number of emerged plants expressed as a percent of control plants ${ }^{a}$

\begin{tabular}{|c|c|c|c|c|c|}
\hline \multirow{2}{*}{\multicolumn{2}{|c|}{$\begin{array}{l}\text { Sample } \\
\text { concentration in } \\
\text { soil ( } \mathrm{mg} \mathrm{kg}^{-1} \text { of } \\
\text { soil d.w.) }\end{array}$}} & \multicolumn{2}{|c|}{$\begin{array}{l}\text { Number of } \\
\text { emerged seedlings }\end{array}$} & \multicolumn{2}{|c|}{ Germination \% } \\
\hline & & \multirow{2}{*}{$\frac{\text { Oat }}{18}$} & \multirow{2}{*}{$\begin{array}{l}\text { Radish } \\
15\end{array}$} & \multirow{2}{*}{$\begin{array}{l}\text { Oat } \\
100\end{array}$} & \multirow{2}{*}{$\frac{\text { Radish }}{100}$} \\
\hline $2 a$ & Control & & & & \\
\hline & 1 & 19 & 15 & 106 & 102 \\
\hline & 10 & 19 & 13 & 109 & 91 \\
\hline & 100 & 19 & 13 & 106 & 86 \\
\hline & 200 & 19 & 11 & 108 & 77 \\
\hline & 400 & 18 & 9 & 104 & 64 \\
\hline & 800 & 17 & 7 & 94 & 50 \\
\hline & 1000 & 14 & $\mathrm{x}$ & 79 & $\mathrm{x}$ \\
\hline \multirow[t]{8}{*}{$2 b$} & Control & 19 & 15 & 100 & 100 \\
\hline & 1 & 18 & 14 & 93 & 100 \\
\hline & 10 & 19 & 14 & 97 & 98 \\
\hline & 100 & 19 & 14 & 95 & 100 \\
\hline & 200 & 19 & 11 & 98 & 79 \\
\hline & 400 & 19 & 12 & 97 & 81 \\
\hline & 800 & 19 & 11 & 98 & 77 \\
\hline & 1000 & 16 & $\mathrm{x}$ & 83 & $\mathrm{x}$ \\
\hline \multirow[t]{8}{*}{$2 c$} & Control & 20 & 18 & 100 & 100 \\
\hline & 1 & 20 & 19 & 102 & 102 \\
\hline & 10 & 20 & 16 & 100 & 85 \\
\hline & 100 & 19 & 17 & 98 & 95 \\
\hline & 200 & 19 & 17 & 98 & 91 \\
\hline & 400 & 19 & 16 & 98 & 85 \\
\hline & 800 & 18 & 14 & 93 & 78 \\
\hline & 1000 & 18 & 13 & 93 & 71 \\
\hline \multirow[t]{8}{*}{$2 d$} & Control & 19 & 15 & 100 & 100 \\
\hline & 1 & 19 & 14 & 100 & 91 \\
\hline & 10 & 19 & 14 & 100 & 91 \\
\hline & 100 & 19 & 14 & 98 & 93 \\
\hline & 200 & 19 & 14 & 100 & 91 \\
\hline & 400 & 19 & 14 & 98 & 91 \\
\hline & 800 & 19 & 13 & 98 & 87 \\
\hline & 1000 & 19 & 13 & 97 & 85 \\
\hline
\end{tabular}

observed for dibenzyl $N$-(4-methylphenyl)amino-(ferrocenyl) methylphosphonate $\mathbf{2 d}\left(\mathrm{EC}_{50}\right.$ was not measured) and the same compound showed relatively low toxicity for radish, i.e. $1036 \mathrm{mg}$ $\mathrm{kg}^{-1}$ of soil.

Values of no observed effect concentration (NOEC) and lowest observed effect concentration (LOEC), determined for fresh matter of both plants (Fig. 1d) correspond to values of $\mathrm{EC}_{50}$. In the case of oat, a low $\mathrm{EC}_{50}$ value for sample $\mathbf{2 a}$ in comparison to high values of NOEC and LOEC was caused by the fact that when no changes in fresh matter content were observed in the concentration range $100-800 \mathrm{mg} \mathrm{kg}^{-1}$ of soil dry weight, the highest concentration significantly decreased the level of fresh matter in oat seedlings and the inhibition growth reached $63 \%$. The calculation made by GraphPad Prism software essentially decreased the value of $\mathrm{EC}_{50}$ calculated for the fresh matter of oat. For the compound 2d, the NOEC/LOEC values distinctly demonstrate the difference between the action of this compound on oat and radish (no effect for oat up to $1000 \mathrm{mg} \mathrm{kg}^{-1}$ of soil $v s$. LOEC $=400 \mathrm{mg}$ for radish).

The percentages of oat sprouts germination for dimethyl aminophosphonates $\mathbf{2 a - d}$ at their highest concentration (1000 $\mathrm{mg} \mathrm{kg}^{-1}$ of soil dry weight) when compared to control plants were 79, 83, 93 and 97\%, respectively (Table 2). In the case of the radish, all tested substances exhibited stronger negative impact against the germination of the common radish. At the highest applied concentration, the percent of germination decrease observed for compounds $\mathbf{2 a}$ and $\mathbf{2 b}$ reached $100 \%$, referring to untreated plants, while for aminophosphonates 2c and $2 \mathbf{d}$, these values were 71 and $85 \%$, respectively. It is worth noting that respectively, dimethyl derivatives $\mathbf{2 a}$ and $\mathbf{2 b}$ exhibited 50 and $77 \%$ of inhibition in the germination of sprouts, already at the concentration of $800 \mathrm{mg}$ per $\mathrm{kg}$ of soil. As has been revealed in the case of shoot, root and fresh matter inhibition, the examination of radish germination has also proved that the radish is much more sensitive to all tested compounds, and that dimethyl aminophosphonates $\mathbf{2} \mathbf{a}-\mathbf{b}$ are much more harmful to the tested plants than their dibenzyl analogues 2c-d.

Digital photographs of the emerged seedlings and roots of the oat and common radish plants treated with the aminophosphonate 2 a one day before the determination of phytotoxicity are presented in Fig. 2, while similar pictures for compounds $\mathbf{2 b - d}$ are presented in ESI as Fig. S15-17. $\dagger$ The photographs exhibit morphological changes like necrosis, chlorosis or any other damage.

Changes in the dry weight of plants treated with growing concentrations of tested compounds are presented in Fig. 3. As expected, the dry weights of both tested plants have increased at the highest concentrations of investigated compounds $\mathbf{2 a - d .}$

Since plants take in nutrients and water through their roots, their growth and development to a large extent depend on the composition and concentration of mineral nutrients available in the soil. At the beginning of the plant's growth, the plant absorbs the nutrients or contaminants very intensively. When the concentration of xenobiotics in the plant is high enough, one of the defence mechanisms against toxic compounds is activated, i.e. the plants absorb large amounts of water in order 


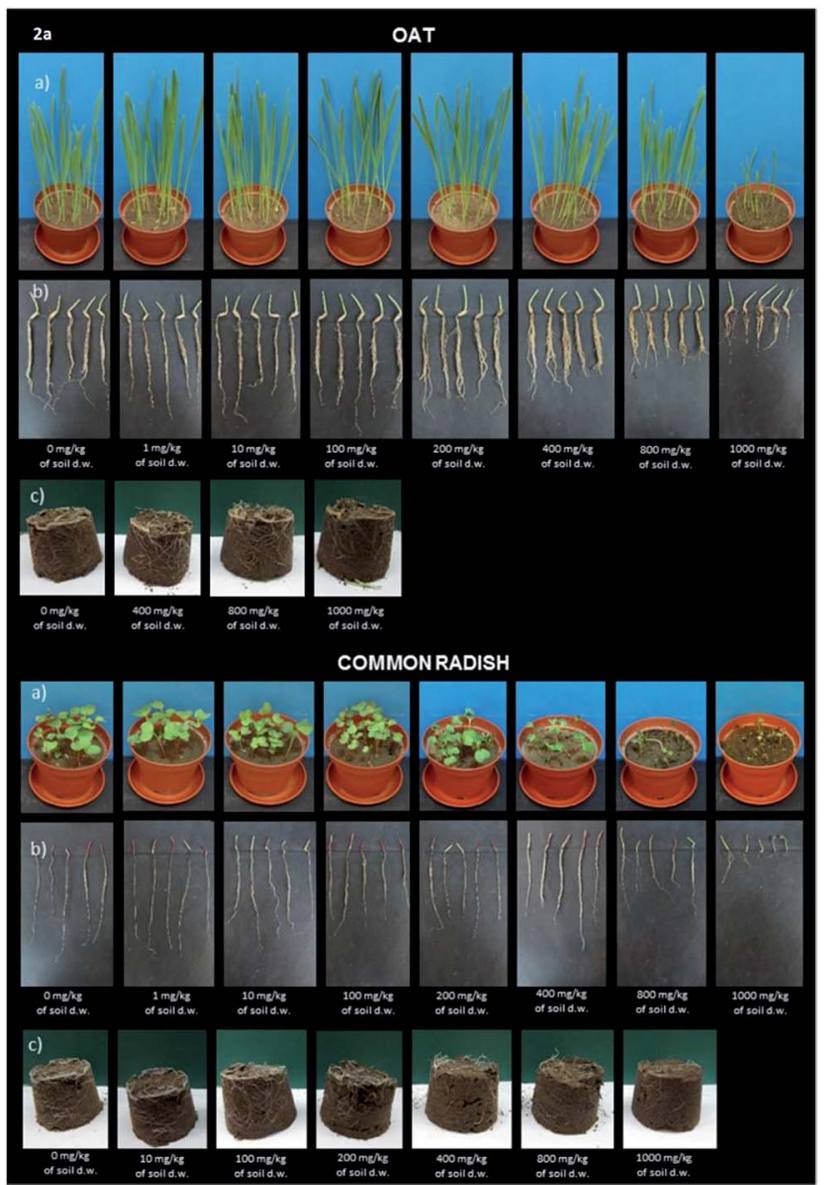

Fig. 2 Digital photographs of oat and radish seedlings treated with sample 2a. (a) The green parts of plants (shoots), (b) roots, (c) the extent of the branching of roots in soil.

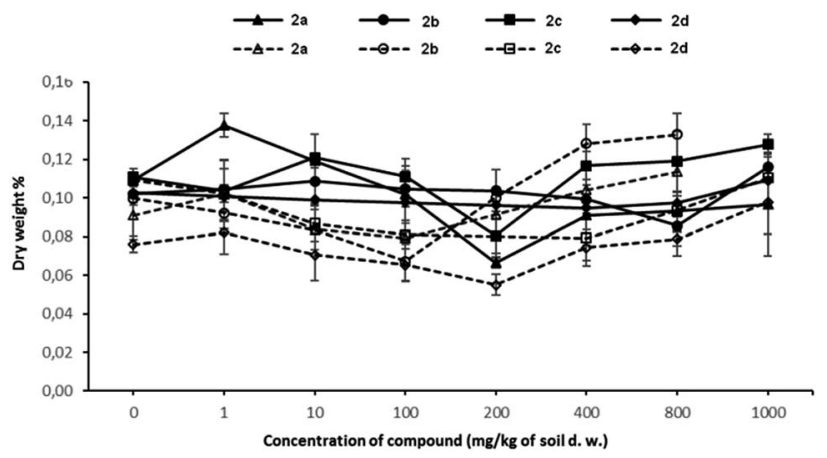

Fig. 3 Changes in the dry weight of treated plants, expressed as a percent of the value in untreated plants $2 a-d$ (control plants $=100 \%$ of dry weight). Solid lines represent changes in oat dry weight. Dotted lines represent changes in radish dry weight.

to start the detoxification process. Unfortunately, after a longer exposure time to contaminants, dysfunction of the roots makes absorbing water and soluble nutrients impossible, therefore, the amount of dry matter in the plant increases.

The changes in the water content in plants seem to be the typical behaviour of plants defending against tested xenobiotics. It is worth noting that oat behaves differently in contact with compound $\mathbf{2 d}$, which is totally harmless to this plant. In this case, the dry weight\% values remain almost unchanged in increasing concentration of the compound $\mathbf{2 d}$.

Results related to the total chlorophyll and carotenoid level in oat and radish seedlings treated with aminophosphonates 2a-d are presented in Fig. 4. Dibenzyl aminophosphonate 2d did not cause any changes in chlorophyll and carotenoid levels in oat seedlings, as in the case of the shoot and root. For comparison, the growing concentration of this compound (2d) in soil caused a significant decrease in the chlorophyll levels in radish seedlings.

Dimethyl ester 2a, considered until now to be the most toxic, caused a significant increase in carotenoid content in oat seedlings with growing concentration in soil, while its slightly negative impact on the chlorophyll level was observed only in radish seedlings.

The aminophosphonate $\mathbf{2 b}$ was totally inert on the level of pigments in both tested plants. Only small, statistically unimportant changes were observed when compared to the untreated, control plants. The highest applied concentration of dibenzylaminophosphonate $2 \mathrm{c}\left(1000 \mathrm{mg} \mathrm{kg}{ }^{-1}\right.$ of soil dry weight) caused a decrease in both pigments in oat seedlings. In the case of radish, the drop in chlorophyll content was observed for the compound $2 \mathrm{c}$ at concentrations of 800 and $1000 \mathrm{mg} \mathrm{kg}^{-1}$ of soil dry weight, while the carotenoid level increased slightly at the highest concentration. The growing carotenoid content indicates the first symptoms of chlorosis of oat seedlings (Fig. 4b).

\section{Microtox assay}

Values of $\mathrm{EC}_{50}$ calculated by the Microtox Analyzer software are plotted in Fig. 5 and listed in Table 3.

Based on the obtained results of $\mathrm{EC}_{50}$ values related to the ecotoxicological impact against Vibrio fischeri bacteria, the compound 2a was revealed as the most toxic $\left(48.3 \mathrm{mg} \mathrm{kg}^{-1}\right.$ of soil dry weight). Surprisingly, aminophosphonate 2d exhibited a similar $\mathrm{EC}_{50}$ value at the level of $59.2 \mathrm{mg} \mathrm{kg}^{-1}$ of soil dry weight. In contrast, compounds $2 \mathbf{b}$ and $2 \mathbf{c}$ expressed 3-4 times higher values of $\mathrm{EC}_{50}$, which correspond to much lower ecotoxicity when compared to samples $\mathbf{2 a}$ and $\mathbf{2 d}$.

\section{Ostracod test kit}

Mortality evaluation using Heterocypris incongruens has shown various effects of tested substances 2a-d. Generally, as expected, the higher the concentration of samples in soil, the higher the mortality (Fig. 6).

Among the tested samples, the highest mortality of Heterocypris incongruens was revealed for sample 2c. At the highest concentration (250 mg kg-1 of soil dry weight), the percent of mortality reached more than $70 \%$. In contrast, the lowest dead impact against tested organisms was observed for sample 2d. At the highest applied concentration, the percentage value of mortality was about 14 , which is five times lower, compared to sample $2 \mathbf{c}$ at the same concentration. 


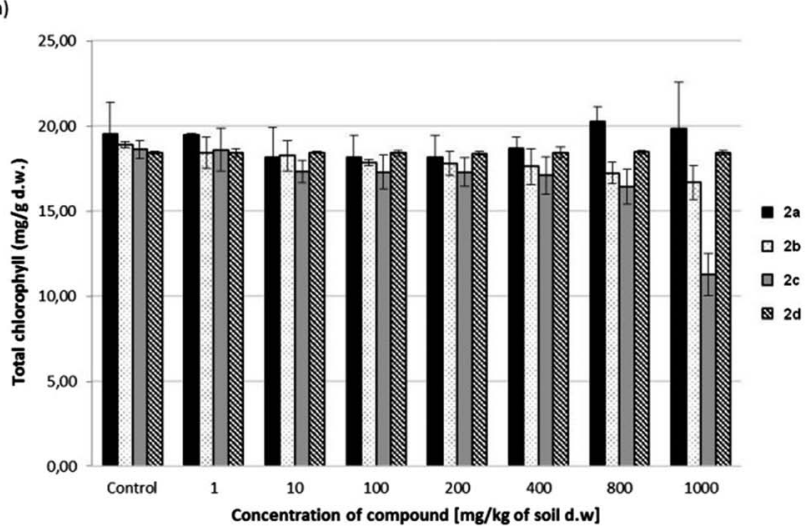

$$
\text { c) }
$$

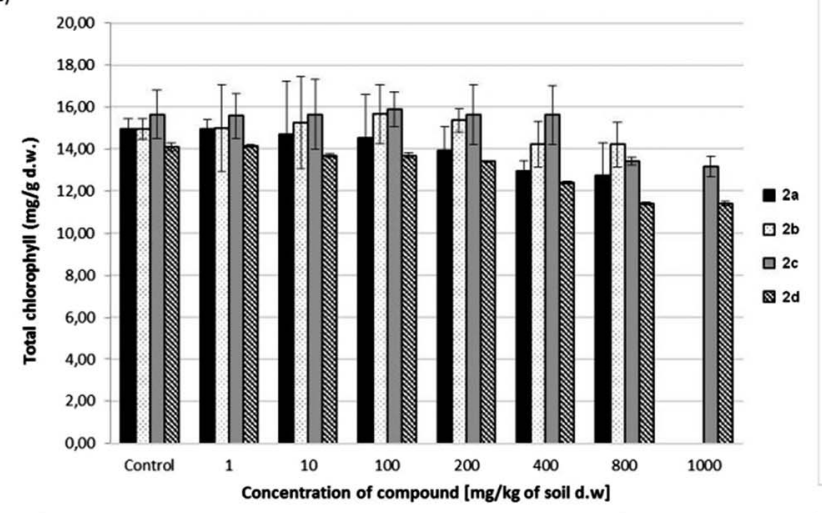

b)

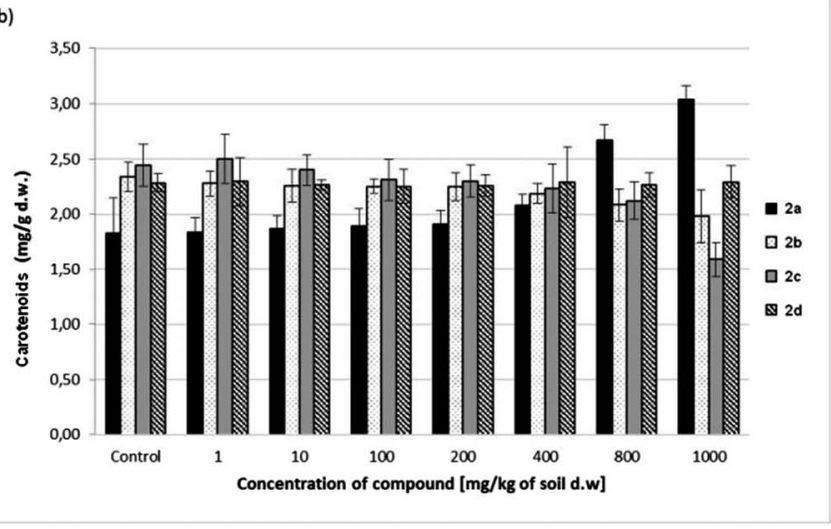

d)

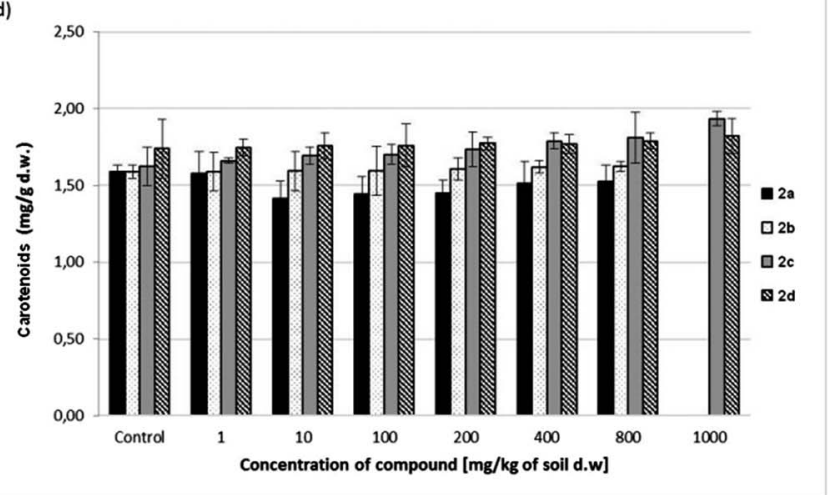

Fig. 4 Effect of $2 a-d$ on the total chlorophyll content (a) and carotenoids (b) in oat seedlings, and the content of total chlorophyll (c) and carotenoids (d) in radish leaves. Data are expressed as mean \pm SD of three replicates for each concentration.

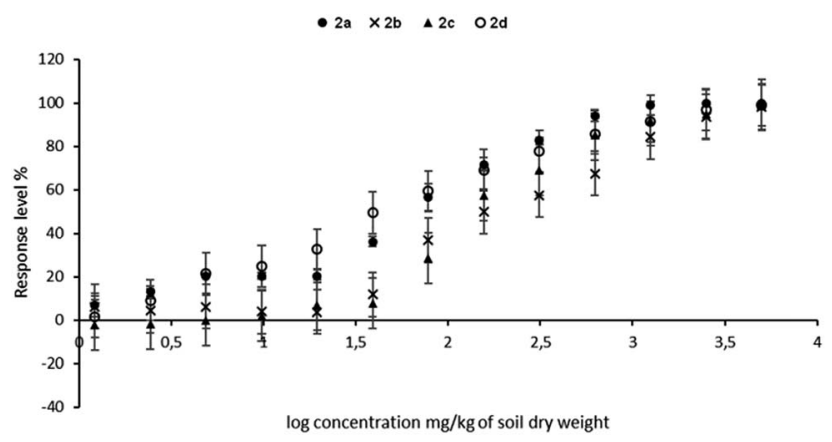

Fig. 5 The $\mathrm{EC}_{50}$ graded dose-response curves for the tested compounds $2 \mathrm{a}-\mathrm{d}$. Overlapped curves were plotted by Microtox ${ }^{\circledR}$ Analyzer 500 software. Error bars represent standard deviation errors (SD, $n=3$ determinations).

Apart from mortality, growth inhibition is the second criterion of the toxic effect indicated by the Ostracodtoxkit $\mathrm{F}^{\mathrm{TM}}$ microbiotest. This criterion allows the evaluation of the sublethal toxicity of sediments. The growth inhibition was determined by comparing the size of the surviving ostracods living in the test sediment with the size of ostracods living in the reference sediment at the end of the test. Determination of the sublethal impact of sediment toxicants was justified only for sediments that do not cause a high ostracod mortality. According to the manual of the Ostracodtoxkit test, ${ }^{34}$ the growth inhibition should only be determined for sediments, where the mortality was found to be less than $30 \%$. Therefore, the growth inhibition was chosen as a criterion of sub-lethal effects to determine toxicity not inducing substantial mortality in tested organisms, therefore, measurements of the length of organisms were only performed for compounds causing mortality less than $30 \%$.

Percentage growth inhibition reports for ostracods treated with increasing concentration of samples $\mathbf{2 a - d}$ coincide with the mortality of these crustaceans. The lowest growth inhibition of ostracods was noticed for sample $\mathbf{2 d}$, which reached the highest concentration at only $22 \%$, compared to untreated crustaceans (Table 4). The results of the growth inhibition of

Table 3 Microtox ${ }^{\circledR} \mathrm{EC}_{50}$ values $\left(\mathrm{mg} \mathrm{kg}^{-1}\right.$ of soil dry weight) of exposure of the luminescent marine bacteria Vibrio fischeri to the tested aminophosphonates $2 \mathrm{a}-\mathrm{d}$ with respective $95 \%$ confidence limits (in brackets) obtained in the fit of the data

\begin{tabular}{lll}
\hline Compounds & EC $_{50}$ (lower limit; upper limit) & $\begin{array}{l}\text { Coefficient of } \\
\text { determination }\left(R^{2}\right)\end{array}$ \\
\hline 2a & $48.3(34.7 ; 67.1)$ & 0.8954 \\
2b & $183.9(124.2 ; 272.3)$ & 0.8895 \\
2c & $234.9(203.1 ; 271.8)$ & 0.9786 \\
2d & $59.2(48.0 ; 73.0)$ & 0.9657
\end{tabular}




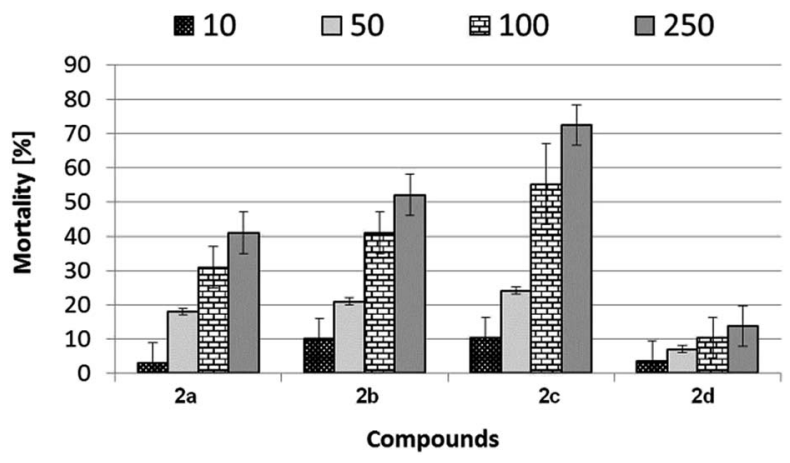

Fig. 6 The mortality (\%) of Heterocypris incongruens living in soil contaminated with aminophosphonates $2 a-d$ at concentrations of 10 , 50,100 and $250 \mathrm{mg} \mathrm{kg}^{-1}$ of soil dry weight. Error bars represent standard deviation error (SD, $n=6$ determinations).

Table 4 Growth inhibition (\%) of Heterocypris incongruens living in soil contaminated with aminophosphonates $2 a-d$ at concentrations of $10,50,100$ and $250 \mathrm{mg} \mathrm{kg}^{-1}$ of soil dry weight. SD means standard deviation (SD, $n=6$ determinations). NM means not measured because mortality was higher than $30 \%$

\begin{tabular}{|c|c|c|c|c|}
\hline \multirow{2}{*}{$\begin{array}{l}\text { Concentration } \\
{\left[\mathrm{mg} \mathrm{kg}^{-1} \text { of soil d.w.] }\right.}\end{array}$} & \multicolumn{4}{|c|}{ Growth inhibition [\%] } \\
\hline & $2 a$ & $2 \mathbf{b}$ & $2 c$ & $2 d$ \\
\hline Control & 0 & 0 & 0 & 0 \\
\hline 10 & $0 \pm 1$ & $2 \pm 1$ & $2 \pm 1$ & $0 \pm 1$ \\
\hline 50 & $10 \pm 1$ & $13 \pm 1$ & $14 \pm 2$ & $7 \pm 1$ \\
\hline 100 & $19 \pm 2$ & NM & NM & $11 \pm 1$ \\
\hline 250 & $\mathrm{NM}$ & NM & NM & $22 \pm 2$ \\
\hline
\end{tabular}

ostracods coincide with their mortality. The highest growth inhibition was noticed for samples $2 \mathbf{b}$ and $2 \mathbf{c}$ and was reached with the concentration of $50 \mathrm{mg} \mathrm{kg}^{-1}$ of soil dry weight, $c a .14 \%$. At the higher concentration level (100 and $250 \mathrm{mg} \mathrm{kg}^{-1}$ of soil dry weight), the growth inhibition, according to recommendations in the Ostracodtoxit test manual ${ }^{34}$ was not measured. Sample 2a was slightly less toxic and its highest measurable inhibition was $19 \%$ for the concentration of $250 \mathrm{mg} \mathrm{kg}^{-1}$ of soil.

\section{Conclusions}

Based on the ecotoxicological assessment of the newly synthesized $N$-arylamino(ferrocenyl)methylphosphonates, a few conclusion can be drawn from the work:

Plant responses to tested compounds are dose dependent. $\mathrm{EC}_{50}$ values, which correspond to the growth inhibition of the shoot, root and fresh matter have proved that the dimethyl esters $\mathbf{2} \mathbf{a}$ and $\mathbf{2 b}$ are the most toxic against tested plants, and the dicotyledonous radish has been revealed as the more sensitive plant, compared to the monocotyledonous oat. Dibenzyl $\mathrm{N}$-(4methoxyphenyl)amino(ferrocenyl)methylphosphonate showed moderate, but non-selective toxicity against both plants. All three compounds, 2a-c, were toxic for crustaceans Heterocypris incongruens, but paradoxically, aminophosphonates $\mathbf{2 b - c}$ were found to be harmless for bacteria
Vibrio fischeri; dimethyl N-(4-methoxyphenyl)amino-(ferrocenyl) methylphosphonate (2a) was effectively toxic for this microbe.

Dibenzyl $\quad N$-(4-methylphenyl)amino(ferrocenyl)methylphosphonate (2d) was almost non-toxic for all of the tested parameters of oat seedlings, while its impact on radish seedlings showed the important symptoms of its moderate toxicity against this plant. It also presented the lowest negative impact against Heterocypris incongruens. Results of the action of the aminophosphonate $\mathbf{2 d}$ on the Vibrio fischeri bacteria showed its important toxicity, thus spoiling the ideality of this compound with respect to its potential herbicidal applications. Nevertheless, compound 2d seems to be a good candidate for further investigation in terms of its probable application as herbicide: it is completely non-toxic to monocotyledonous oat, practically harmless for crustaceans and although moderately toxic for dicotyledonous radish, and it is able to negatively influence radish roots.

The ecotoxicological impact of dimethyl $\mathrm{N}$-(4-methylphenyl) amino-(ferrocenyl)methylphosphonate (2b) is equally interesting. Its phytotoxicity is also significantly selective, as its $\mathrm{EC}_{50}$ values for radish are several times smaller, when compared to the corresponding values for oat. The compound $\mathbf{2 b}$ is relatively harmless to Vibrio fischeri but, unfortunately, it is toxic to Heterocypris incongruens. Although ecotoxicologically ambiguous, these two compounds have shown their potential; therefore, their phytotoxicity will be investigated more profoundly, e.g. their impact on persistent weeds.

\section{Conflict of interest}

There are no conflicts of interest to declare.

\section{Acknowledgements}

Studies were founded by the National Centre of Science of Polish State (NCN), grant no. 2014/13/B/NZ9/02418. Costs of publishing in the open access system are covered by the Faculty of Chemistry, University of Łódź.

\section{Notes and references}

1 P. Kafarski and B. Lejczak, Phosphorus, Sulfur Silicon Relat. Elem., 1991, 63, 193.

2 G. Forlani, Ł. Berlicki, M. Duò, G. Dziędzioła, S. Giberti, M. Bertazzini and P. Kafarski, J. Agric. Food Chem., 2013, 61, 6792.

3 A. Occhipinti, Ł. Berlicki, S. Giberti, G. Dziędzioła, P. Kafarski and G. Forlani, Pest Manage. Sci., 2010, 66, 51.

4 S. Giberti, M. Bertazzini, M. Liboni, Ł. Berlicki, P. Kafarski and G. Forlani, Pest Manage. Sci., 2017, 73, 435.

5 E. C. Constable, Angew. Chem., Int. Ed. Engl., 1991, 30, 407. 6 S. Top, A. Vessières, C. Cabestaing, I. Laios, G. Leclercq, C. Provot and G. Jaouen, J. Organomet. Chem., 2001, 637639, 500.

7 E. A. Hillard, A. Vessières, S. Top, P. Pigeon, K. Kowalski, M. Huche and G. Jaouen, J. Organomet. Chem., 2007, 692, 1315. 
8 A. Nguyen, S. Top, A. Vessières, P. Pigeon, M. Huché, E. A. Hillard and G. Jaouen, J. Organomet. Chem., 2007, 692, 1219.

9 C. Roux and C. Biot, Future Med. Chem., 2012, 4, 783.

10 N. Metzler-Nolte and M. Salmain, in Ferrocenes. Ligands, Materials and Biomolecules, ed. P. Stepnicka, J. Wiley\&Sons Ltd, Chichester, 2008, p. 619.

11 B. Floris, Chem. Biol. Technol. Agric., 2015, 2, 15.

12 (a) J. Lewkowski, M. Rzeźniczak, R. Skowroński and J. Zakrzewski, J. Organomet. Chem., 2001, 631, 105; (b) J. Lewkowski, M. Rzeźniczak and R. Skowroński, Heteroat. Chem., 2003, 14, 144; (c) J. Lewkowski, J. Organomet. Chem., 2003, 681, 225; (d) J. Lewkowski, M. Rzeźniczak and R. Skowroński, J. Organomet. Chem., 2004, 689, 1265; (e) J. Lewkowski, M. Rzeźniczak and R. Skowroński, J. Organomet. Chem., 2004, 689, 1684; (f) J. Lewkowski and R. Skowroński, Pol. J. Chem., 2005, 79, 525; $(g)$ J. Lewkowski, R. Skowroński, D. Krasowska and R. Karpowicz, Tetrahedron Lett., 2006, 47, 1589; (h) J. Lewkowski and R. Karpowicz, Pol. J. Chem., 2007, 81, 2097; (i) J. Lewkowski, R. Karpowicz and R. Skowroński, Phosphorus, Sulfur Silicon Relat. Elem., 2009, 184, 815; (j) J. Lewkowski, R. Karpowicz, E. Miękoś and M. Zieliński, Heteroat. Chem., 2014, 25, 163.

13 Terrestrial plant test: 208: Seedling emergence and seedling growth test, in OECD Guideline for the testing of chemicals, Organization For Economic Co-Operation and Development, Paris, France, 1984.

14 (a) L.-S. Wang, L. Wang, L. Wang, G. Wang, Z.-H. Li and J.-J. Wang, Environ. Toxicol., 2009, 24, 296; (b) B. Pawlowska and R. Biczak, Chemosphere, 2016, 149, 24.

15 A. Oren, M. Kuehl and U. Karsten, Mar. Ecol.: Prog. Ser., 1995, 128, 151.

16 J. Lewkowski, M. Rodriguez Moya, M. Chmielak, D. Rogacz, K. Lewicka and P. Rychter, Molecules, 2016, 21, 936.

17 K. Doe, R. Scroggins, D. Mcleay and G. Wohlgeschaffen, in Small-Scale Freshwater Toxicity Investigations, ed. C. Blaise and J. F. Férard, Springer, Dordrecht, 2005, vol. 1, pp. 107136.
18 M. J. Martínez-Sánchez, C. Pérez-Sirvent, M. L. GarcíaLorenzo, S. Martínez-López, J. Bech, R. García-Tenorio and J. P. Bolívar, J. Geochem. Explor., 2014, 147, 130.

19 H. R. Hudson, in Aminophosphonic and Aminophosphinic Acids. Chemistry and Biological Activity, ed. V. P. Kukhar and H. R. Hudson, John Wiley \& Sons, New York, 2000, p. 443.

20 H. Kleszczynska, J. Sarapuk and D. Bonarska, Cell. Mol. Biol. Lett., 2001, 6, 271.

21 S. Sobhani and Z. Tashrifi, Tetrahedron, 2010, 66, 1429.

22 C. S. Sundari, N. B. Reddy, S. S. Prasad, K. U. M. Rao, S. H. J. Prakash and C. S. Reddy, Phosphorus, Sulfur Silicon Relat. Elem., 2014, 180, 551.

23 P. P. Onys'ko, K. A. Zamulko, O. I. Kyselyova, I. P. Yelenich and Y. V. Rassukana, J. Fluorine Chem., 2016, 185, 191.

24 Z. M. Jászay, G. Németh, T. S. Pham, I. Petneházy, A. Grün and L. Töke, Tetrahedron: Asymmetry, 2005, 16, 3837.

25 W. W. Smith and P. A. Bartlett, J. Am. Chem. Soc., 1998, 120, 4622.

26 T. E. Ali and S. M. El-Edfawy, Res. Chem. Intermed., 2016, 42, 1329.

27 G. Yang, Z. Liu, J. Liu and H. Yang, Heteroat. Chem., 2000, 11, 313.

28 K. M. Yager, C. M. Taylor and A. B. Smith, J. Am. Chem. Soc., 1994, 116, 9377-9378.

29 I. M. Lefebvre and S. A. J. Evans, J. Org. Chem., 1997, 62, 7532. 30 Z. Rezaei, S. Khabnadideh, K. Zomorodian, K. Pakshir, S. Nadali, N. Mohtashami and E. F. Mirzaei, Int. J. Med. Chem., 2011, 678101.

31 J. Lewkowski, Z. Malinowski, A. Matusiak, M. Morawska, D. Rogacz and P. Rychter, Molecules, 2016, 21, 694.

32 A. Matusiak, J. Lewkowski, P. Rychter and R. Biczak, J. Agric. Food Chem., 2013, 61, 7673.

33 R. Biczak, B. Pawłowska, P. Bałczewski and P. Rychter, J. Hazard. Mater., 2014, 274, 181.

34 MicroBioTests, Toxkit Advantages/Assets, available online: http://www.microbiotests.be/information/toxkitadvantagesassets/, accessed on 19 July 2016. 